\title{
Effects of Intake of Soy and Non-Soy Legume on Serum HDL-Cholesterol Levels
}

\author{
Hidekatsu Yanai ${ }^{\mathrm{a}, \mathrm{c}}$, Norio Tada ${ }^{\mathrm{b}}$
}

\begin{abstract}
High-density lipoprotein (HDL) has been shown to have a variety of functions that contribute to anti-atherogenesis. Here we review metaanalyses on the effects of intake of soy protein and isoflavones on serum HDL-cholesterol (HDL-C) levels, and we would also review meta-analysis on the effects of intake of non-soy legume on serum HDL-C, to make "Dietary Reference Intake for Japanese 2020". We searched meta-analyses of randomized, placebo-controlled trials. A search was conducted by using PubMed, Embase and Google Scholar, with the following keywords: soy and HDL and meta-analysis. The search period was comprised from 2007 up to July 2018. We found three meta-analyses about effects of intake of soy protein and isoflavones on HDL-C after 2007. All meta-analyses reported that intake of soy protein and isoflavones was associated with a significant increase of HDL-C. We found the meta-analysis which evaluated effects of intake of non-soy legume on HDL-C, in which a significant association of intake of non-soy legume with HDL-C was not obtained due to a significant heterogeneity of collected data. In conclusion, intake of soy was significantly associated with elevation of HDL-C; however, non-soy consumption was not associated with a significant increase of HDL.
\end{abstract}

Keywords: High-density lipoprotein; Isoflavones; Non-soy legume; Soy protein

\section{Introduction}

High-density lipoprotein (HDL) has been shown to have a variety of functions that contribute to anti-atherogenesis: reverse cholesterol transport from the peripheral tissues to liver, promotion of macrophage cholesterol efflux, anti-inflammatory and anti-oxidative effects [1-3]. Therefore, low HDL-choles-

Manuscript submitted July 20, 2018, accepted August 27, 2018

a Department of Internal Medicine, National Center for Global Health and Medicine Kohnodai Hospital, Chiba, Japan

${ }^{\mathrm{b}}$ The Jikei University School of Medicine, Tokyo, Japan

${ }^{\mathrm{c} C}$ Corresponding Author: Hidekatsu Yanai, Department of Internal Medicine, National Center for Global Health and Medicine Kohnodai Hospital, 1-7-1 Kohnodai, Chiba 272-8516, Japan. Email: dyanai@hospk.ncgm.go.jp

doi: https://doi.org/10.14740/jem524w terol (HDL-C) level is significantly associated with the development of coronary artery diseases (CADs) $[4,5]$.

\section{Soy protein and isoflavones have been proposed to reduce the risk of CAD.}

We previously studied effects of intake of soy protein and isoflavones on serum HDL-C levels to make "Dietary Reference Intakes for Japanese 2015", by using data obtained by clinical trials which evaluated effects of intake of soy protein and isoflavones on HDL-C in Asian populations, and data obtained from meta-analyses [6]. In the analysis of randomized, placebo-controlled trials (RCTs) to evaluate effects of soy protein and isoflavones on HDL-C which were performed in Asian populations, three RCTs denied a significant effect of intake of soy protein and isoflavones on serum HDL-C [7-9]. However, in two RCTs which investigated the effects of combination of isoflavones intake and walking, serum HDL-C significantly increased $[10,11]$. The meta-analyses performed before 2007 showed a beneficial effect of intake of soy protein and isoflavones on serum HDL-C [12-15].

Here we review meta-analyses on the effects of intake of soy protein and isoflavones on serum HDL-C levels, and we would also review meta-analysis on the effects of intake of non-soy legume on serum HDL-C, to make "Dietary Reference Intake for Japanese 2020".

\section{Materials and Methods}

To make "Dietary Reference Intake for Japanese 2020", we searched meta-analyses of RCTs. A search was conducted by using PubMed, Embase and Google Scholar, with the following keywords: soy and HDL and meta-analysis. The search period was comprised from 2007 up to July 2018.

\section{Results}

Meta-analyses evaluated effects of intake of soy protein and isoflavones on HDL-C were shown in Table 1.

We found three meta-analyses about effects of intake of soy protein and isoflavones on HDL-C after 2007 [16-18]. All meta-analyses reported that intake of soy protein and isoflavones was associated with a significant increase of HDL-C. 
Table 1. Meta-Analyses Evaluated Effects of Intake of Soy Protein and Isoflavones on HDL-C

\begin{tabular}{|c|c|c|c|c|}
\hline Authors & Assessed studies & Subjects studied & Effects on HDL-C & Effects on other lipids and glucose metabolism \\
\hline $\begin{array}{l}\text { Tokede et } \\
\text { al [16] }\end{array}$ & $\begin{array}{l}\text { RCTs assessing the effects } \\
\text { of soy on the lipid profile }\end{array}$ & $\begin{array}{l}35 \text { studies were } \\
\text { included. Treatment } \\
\text { duration ranged } \\
\text { from } 4 \text { weeks } \\
\text { to } 1 \text { year }\end{array}$ & $\begin{array}{l}\text { There was a significant } \\
\text { increase in serum } \\
\text { HDL-C, } 1.40 \text { ( } 95 \% \mathrm{CI} \text { : } \\
0.58-2.23) \mathrm{mg} / \mathrm{dL}\end{array}$ & $\begin{array}{l}\text { Intake of soy products resulted in a significant } \\
\text { reduction in serum LDL-C, }-4.83 \text { (95\% CI: }-7.34 \\
\text { to }-2.31) \mathrm{mg} / \mathrm{dL}, \mathrm{TG},-4.92(95 \% \mathrm{CI}:-7.79 \text { to } \\
-2.04) \mathrm{mg} / \mathrm{dL} \text {, and } \mathrm{TC},-5.33(95 \% \mathrm{CI}:-8.35 \text { to } \\
-2.30) \mathrm{mg} / \mathrm{dL}\end{array}$ \\
\hline $\begin{array}{l}\text { Yang et } \\
\text { al [17] }\end{array}$ & $\begin{array}{l}\text { RCTs were included } \\
\text { in which soy products } \\
\text { supplementation was the } \\
\text { only intervention in subjects } \\
\text { with type } 2 \text { diabetes }\end{array}$ & $\begin{array}{l}\text { Eight studies were } \\
\text { included according } \\
\text { to the criteria }\end{array}$ & $\begin{array}{l}\text { The intake of } \\
\text { soy products was } \\
\text { associated with a } \\
\text { significant increase in } \\
\text { HDL-C }(0.05 \mathrm{mmol} / \mathrm{L} \text {; } \\
95 \% \text { CI: } 0.04-0.06)\end{array}$ & $\begin{array}{l}\text { The intake of soy products was associated with a } \\
\text { significant reduction in TC (by } 0.42 \mathrm{mmol} / \mathrm{L} ; 95 \% \\
\text { CI: }-0.70 \text { to }-0.14 \text { ), TG (by } 0.22 \mathrm{mmol} / \mathrm{L} ; 95 \% \\
\text { CI: }-0.38 \text { to }-0.07 \text { ) and LDL-C (by } 0.30 \mathrm{mmol} / \mathrm{L} \text {; } \\
95 \% \text { CI: }-0.60 \text { to }-0.00 \text { ). There were no significant } \\
\text { effects on fasting glucose, insulin and glycated } \\
\text { hemoglobin }\end{array}$ \\
\hline $\begin{array}{l}\text { Anderson } \\
\text { et al [18] }\end{array}$ & $\begin{array}{l}\text { RCTs related to soy } \\
\text { protein intake and serum } \\
\text { lipoprotein changes }\end{array}$ & $\begin{array}{l}\text { Analyses included } \\
20 \text { parallel-design } \\
\text { studies and } 23 \\
\text { crossover studies }\end{array}$ & $\begin{array}{l}\text { In parallel studies, } \\
\text { net serum HDL-C } \\
\text { values were } 3.2 \% \\
\text { higher }(\mathrm{P}<0.007) \text { with } \\
\text { soy versus control }\end{array}$ & $\begin{array}{l}\text { Soy protein intake was associated with net } \\
\text { changes in } \mathrm{LDL}-\mathrm{C} \text { values of }-0.23 \mathrm{mmol} / \mathrm{L}(95 \% \\
\text { CI: }-0.28 \text { to }-0.18 \mathrm{mmol} / \mathrm{L}) \text { or a } 5.5 \% \text { reduction in } \\
\text { parallel studies and }-0.16 \mathrm{mmol} / \mathrm{L}(95 \% \mathrm{CI}-0.22 \\
\text { to }-0.11 \mathrm{mmol} / \mathrm{L}) \text { or a reduction of } 4.2 \% \text { with } \\
\text { crossover studies }(\mathrm{P}<0.001 \text { for parallel versus } \\
\text { crossover). In parallel studies, TG values were } \\
10.7 \% \text { lower }(\mathrm{P}<0.008) \text { for soy versus control }\end{array}$ \\
\hline
\end{tabular}

Cl: confidence interval; HDL-C: high-density lipoprotein-cholesterol; LDL-C: low-density-cholesterol; RCT: randomized controlled trial; TC: total cholesterol; TG: triglyceride.

We found the meta-analysis which evaluated effects of intake of non-soy legume on HDL-C (Table 2) [19]. Intake of non-soy legume was significantly associated with reduction in total cholesterol (TC) and low-density lipoprotein (LDL)$\mathrm{C}$; however, a significant association of non-soy legume consumption with HDL-C was not obtained due to a significant heterogeneity of collected data.

\section{Discussion}

In our previous study, all meta-analyses suggested that intake of soy protein and isoflavones was significantly associated with elevation of HDL-C [6]. In the present study using metaanalyses published after 2007, we found three studies [16-18].

In the study by Tokede et al, 35 studies were included in their analyses [16]. Treatment duration ranged from 4 weeks to 1 year. Intake of soy products resulted in a significant increase in serum HDL-C, 1.40 (95\% CI: 0.58 - 2.23) $\mathrm{mg} / \mathrm{dl}$, in addition to a significant reduction in serum LDL-C, triglyceride (TG) and TC [16].

Yang et al systematically reviewed the effects of soy products consumption on serum lipid profiles and glycemic control in patients with type 2 diabetes [17]. Eight studies were included according to the criteria. Intake of soy products was associated with a significant increase in HDL-C, in addition to a significant reduction in TC, TG and LDL-C [17]. However, there were no significant effects on fasting glucose, insulin and glycated hemoglobin.

In the study by Anderson et al, RCTs were assessed that met these requirements: soy protein intake compared with nonsoy protein, provided information on serum LDL-C, provided no more than $65 \mathrm{~g}$ of soy protein daily, and obtained LDL$\mathrm{C}$ measurements between 4 and 18 weeks of treatment [18]. Analyses included 20 parallel-design studies and 23 crossover studies. In parallel studies, net serum HDL-C values were

Table 2. Meta-Analysis Evaluated Effects of Intake of Non-Soy Legume on HDL-C

\begin{tabular}{|c|c|c|c|c|}
\hline Authors & Assessed studies & Subjects studied & Effects on HDL-C & Effects on other lipids \\
\hline $\begin{array}{l}\text { Bazzano } \\
\text { et al [19] }\end{array}$ & $\begin{array}{l}\text { RCTs which were selected } \\
\text { which compared a non-soy } \\
\text { legume diet to control, } \\
\text { had a minimum duration } \\
\text { of } 3 \text { weeks, and reported } \\
\text { blood lipid changes during } \\
\text { intervention and control }\end{array}$ & 10 RCTs & $\begin{array}{l}\text { The pooled mean net } \\
\text { change in HDL-C was } \\
0.85 \mathrm{mg} / \mathrm{dL}(95 \% \mathrm{CI} \text { : } \\
-1.62-3.32, \mathrm{P}=0.05 \\
\mathrm{X}^{2} \text { for heterogeneity, } \\
\mathrm{P}=0.005)\end{array}$ & $\begin{array}{l}\text { Pooled mean net change in TC for those treated } \\
\text { with a legume diet compared to control was }-11.8 \\
\mathrm{mg} / \mathrm{dL}(95 \% \mathrm{CI}:-16.1 \text { to }-7.5) \text {; mean net change } \\
\text { in LDL-C was }-8.0 \mathrm{mg} / \mathrm{dL}(95 \% \mathrm{CI}:-11.4 \text { to }-4.6) \text {. } \\
\text { Pooled mean net change in TG was }-18.94 \mathrm{mg} / \mathrm{dL} \\
\left(95 \% \mathrm{CI} \text { : }-38.04-0.17, \mathrm{P}=0.05 ; \mathrm{X}^{2} \text { for }\right. \\
\text { heterogeneity, } \mathrm{P}<0.001)\end{array}$ \\
\hline
\end{tabular}

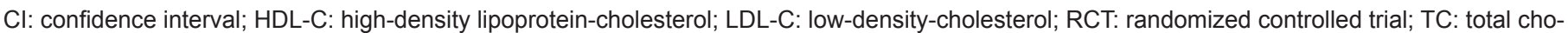
lesterol; TG: triglyceride. 
$3.2 \%$ higher $(\mathrm{P}<0.007)$ with soy versus control $[18]$. Soy protein intake was also associated with reduction in serum LDL-C and TG. Soy protein consumption with a median of $30 \mathrm{~g} /$ day was associated with a significant improvement in lipoprotein risk factors.

Bazzano et al investigated effects of intake of non-soy legume on serum lipids. Ten RCTs were selected which compared a non-soy legume diet to control, had a minimum duration of 3 weeks, and reported blood lipid changes during intervention and control [19]. Although results indicated that a diet rich in legumes other than soy decreases TC and LDL-C, this study did not show a significant association of intake of non-soy legume with HDL-C due to a significant heterogeneity of collected data [19].

Various mechanisms have been suggested by which soy proteins may exert their lipid-lowering effects. The activation of LDL receptors by essential amino acids from soy protein [20], and soy protein-based inhibition of endogenous cholesterol synthesis [21] have been proposed. Further, water-soluble dietary fiber and other components such as isoflavones may also reduce serum lipid levels [22].

Although the hypocholesterolemic effect of soy is well documented, the underlying mechanisms for soy-mediated increase of HDL remain largely unknown. Soy contains additional components, such as isoflavones, lecithins, saponins and dietary fiber that may improve cardiovascular risk factors by independent mechanisms such as hypoglycemic effect, anti-inflammatory effect and anti-obesity effect [23]. Such additional components in soy may be associated with elevation of HDL$\mathrm{C}$, which support no effects of non-soy legume on HDL-C.

\section{Conclusions}

Intake of soy and non-soy legume was significantly associated with reduction of TC and LDL-C. Intake of soy was significantly associated with elevation of HDL-C; however, non-soy consumption was not associated with a significant increase of HDL.

\section{Conflict of Interest}

The authors declare that they have no competing interests.

\section{References}

1. Eren E, Yilmaz N, Aydin O. High Density Lipoprotein and it's Dysfunction. Open Biochem J. 2012;6:78-93.

2. Annema W, Tietge UJ. Role of hepatic lipase and endothelial lipase in high-density lipoprotein-mediated reverse cholesterol transport. Curr Atheroscler Rep. 2011;13(3):257-265.

3. deGoma EM, deGoma RL, Rader DJ. Beyond high-density lipoprotein cholesterol levels evaluating high-density lipoprotein function as influenced by novel therapeutic approaches. J Am Coll Cardiol. 2008;51(23):2199-2211.
4. Kitamura A, Iso H, Naito Y, Iida M, Konishi M, Folsom AR, Sato S, et al. High-density lipoprotein cholesterol and premature coronary heart disease in urban Japanese men. Circulation. 1994;89(6):2533-2539.

5. Yokokawa H, Yasumura S, Tanno K, Ohsawa M, Onoda T, Itai K, Sakata K, et al. Serum low-density lipoprotein to high-density lipoprotein ratio as a predictor of future acute myocardial infarction among men in a 2.7-year cohort study of a Japanese northern rural population. J Atheroscler Thromb. 2011;18(2):89-98.

6. Yanai H, Katsuyama H, Hamasaki H, Abe S, Tada N, Sako A. Effects of soy protein and isoflavones intake on HDL metabolism in Asian populations. J Endocrinol Metab. 2014;4(3):51-55.

7. Liu ZM, Ho SC, Chen YM, Ho YP. The effects of isoflavones combined with soy protein on lipid profiles, Creactive protein and cardiovascular risk among postmenopausal Chinese women. Nutr Metab Cardiovasc Dis. 2012;22(9):712-719.

8. Ye YB, Wang ZL, Zhuo SY, Lu W, Liao HF, Verbruggen $\mathrm{M}$, Fang S, et al. Soy germ isoflavones improve menopausal symptoms but have no effect on blood lipids in early postmenopausal Chinese women: a randomized placebo-controlled trial. Menopause. 2012;19(7):791-798.

9. Ho SC, Chen YM, Ho SS, Woo JL. Soy isoflavone supplementation and fasting serum glucose and lipid profile among postmenopausal Chinese women: a doubleblind, randomized, placebo-controlled trial. Menopause. 2007;14(5):905-912.

10. Wu J, Oka J, Tabata I, Higuchi M, Toda T, Fuku N, Ezaki $\mathrm{J}$, et al. Effects of isoflavone and exercise on BMD and fat mass in postmenopausal Japanese women: a 1-year randomized placebo-controlled trial. J Bone Miner Res. 2006;21(5):780-789.

11. Wu J, Oka J, Higuchi M, Tabata I, Toda T, Fujioka M, Fuku N, et al. Cooperative effects of isoflavones and exercise on bone and lipid metabolism in postmenopausal Japanese women: a randomized placebo-controlled trial. Metabolism. 2006;55(4):423-433.

12. Taku K, Umegaki K, Sato Y, Taki Y, Endoh K, Watanabe S. Soy isoflavones lower serum total and LDL cholesterol in humans: a meta-analysis of 11 randomized controlled trials. Am J Clin Nutr. 2007;85(4):1148-1156.

13. Reynolds K, Chin A, Lees KA, Nguyen A, Bujnowski D, He J. A meta-analysis of the effect of soy protein supplementation on serum lipids. Am J Cardiol. 2006;98(5):633640.

14. Zhan S, Ho SC. Meta-analysis of the effects of soy protein containing isoflavones on the lipid profile. Am J Clin Nutr. 2005;81(2):397-408.

15. Weggemans RM, Trautwein EA. Relation between soyassociated isoflavones and LDL and HDL cholesterol concentrations in humans: a meta-analysis. Eur J Clin Nutr. 2003;57(8):940-946.

16. Tokede OA, Onabanjo TA, Yansane A, Gaziano JM, Djousse L. Soya products and serum lipids: a metaanalysis of randomised controlled trials. Br J Nutr. 2015;114(6):831-843.

17. Yang B, Chen Y, Xu T, Yu Y, Huang T, Hu X, Li D. Sys- 
tematic review and meta-analysis of soy products consumption in patients with type 2 diabetes mellitus. Asia Pac J Clin Nutr. 2011;20(4):593-602.

18. Anderson JW, Bush HM. Soy protein effects on serum lipoproteins: a quality assessment and meta-analysis of randomized, controlled studies. J Am Coll Nutr. 2011;30(2):79-91.

19. Bazzano LA, Thompson AM, Tees MT, Nguyen CH, Winham DM. Non-soy legume consumption lowers cholesterol levels: a meta-analysis of randomized controlled trials. Nutr Metab Cardiovasc Dis. 2011;21(2):94-103.

20. Gianazza E, Lovati M, Manzoni C, et al. Reduction of serum cholesterol by soy proteins: clinical experience and potential molecular mechanisms. Nutr Metab Cardiovasc
Dis. 1998;8:334-340.

21. Tham DM, Gardner CD, Haskell WL. Clinical review 97: Potential health benefits of dietary phytoestrogens: a review of the clinical, epidemiological, and mechanistic evidence. J Clin Endocrinol Metab. 1998;83(7):2223-2235.

22. Erdman JW, Jr. AHA Science Advisory: Soy protein and cardiovascular disease: A statement for healthcare professionals from the Nutrition Committee of the AHA. Circulation. 2000;102(20):2555-2559.

23. Ramdath DD, Padhi EM, Sarfaraz S, Renwick S, Duncan AM. Beyond the cholesterol-lowering effect of soy protein: a review of the effects of dietary soy and its constituents on risk factors for cardiovascular disease. Nutrients. 2017;9(4):324. 